
application of boron, calcium, and Stimulate. Horticultura Brasileira 36: 498-503. DOI: http://dx.doi.org/10.1590/S0102-053620180412

\title{
Fruit yield and gas exchange in bell peppers after foliar application of boron, calcium, and Stimulate
}

\author{
André R Zeist ${ }^{1}$; Daniel S Zanin²; Cristhiano K Camargo ${ }^{3}$; Juliano TV de Resende ${ }^{3}$; Elizabeth O Ono ${ }^{4}$; \\ João D Rodrigues ${ }^{4}$
}

${ }^{1}$ Universidade do Oeste Paulista (UNOESTE), Presidente Prudente-SP, Brazil; andre.zeist@bol.com.br; ${ }^{2}$ Universidade do Estado de Santa Catarina (UDESC), Lages-SC, Brazil; dsuekzanin@gmail.com; ${ }^{3}$ Universidade Estadual do Centro-Oeste (UNICENTRO), Guarapuava-PR, Brazil; kopanski1976@hotmail.com; jvresende@uol.com.br; ${ }^{4}$ Universidade Estadual Paulista (UNESP), Botucatu-SP, Brazil; eoono@ibb.unesp.br; mingo@ibb.unesp.br

\begin{abstract}
The objective of this study was to evaluate the effect of the isolated and combined foliar application of boron, calcium, and the plant growth regulator Stimulate on fruit yield and gas exchange in bell peppers. The evaluated treatments were boron, calcium, Stimulate, boron + calcium, boron + Stimulate, calcium + Stimulate, boron + calcium + Stimulate, and control (water). The study was performed in complete randomized block design with three replicates. The applications were performed biweekly on the plant leaves from the beginning of flowering (December 21, 2013) until March 1, 2014. The analyzed gas exchange characteristics were photosynthetic yield, internal $\mathrm{CO}_{2}$ concentration, and transpiration rate. The evaluated agronomic characteristics were number and yield of marketable and non-marketable fruits, and the average mass, volume, and firmness of commercial fruits. The foliar application of boron from the beginning of flowering increased the photosynthetic yield and the yield of marketable fruits cultivated in the field. The foliar application of calcium and Stimulate did not improve gas exchange and fruit yield. The most common effects of boron were an increase in the number of marketable fruits. Moreover, foliar spraying with calcium from the beginning of flowering increased the firmness of commercial fruits
\end{abstract}

Keywords: Capsicum annuum, leaf fertilizer, photosynthesis.

\section{RESUMO}

Produção e trocas gasosas do pimentão em função da aplicação foliar de boro, cálcio e Stimulate

Objetivou-se com este trabalho avaliar o efeito da aplicação foliar isolada e combinada dos nutrientes boro e cálcio e do regulador de crescimento vegetal comercial Stimulate na produção de frutos e nas trocas gasosas do pimentão. Os tratamentos foram boro; cálcio; Stimulate; boro + cálcio; boro + Stimulate; cálcio + Stimulate; boro + cálcio + Stimulate; e testemunha (água), aplicados via foliar. $\mathrm{O}$ experimento foi conduzido em delineamento de blocos casualizados com três repetições. As aplicações foliares iniciaram a partir do início do florescimento das plantas (21 de dezembro de 2013), com aplicações quinzenais até 01 de março de 2014. Foram avaliadas as características de trocas gasosas: rendimento fotossintético, concentração interna de $\mathrm{CO}_{2}$ e taxa de transpiração; e as agronômicas: número e produtividade de frutos não comerciais e comerciais; e a massa média, volume e firmeza de frutos comerciais. A aplicação foliar de boro a partir do início do florescimento aumentou a fotossíntese e a produção de frutos comercializáveis de pimentão cultivado a campo. Não houve efeitos benéficos da aplicação foliar de cálcio e de Stimulate sobre as trocas gasosas e a produção de frutos de pimentão. Os efeitos mais consistentes do boro foram no aumento do número de frutos comerciais. A pulverização foliar com cálcio a partir do início do florescimento aumentou a firmeza dos frutos comerciais de pimentão.

Palavras-chave: Capsicum annuum, fertilizante foliar, fotossíntese.

\section{Received on September 17, 2017; accepted on October 18, 2018}

$T^{1}$ he application of foliar fertilizers and/or plant regulators may increase the production of fruits and vegetables. Calcium and boron are the nutrients most frequently applied on the leaves of vegetables (Cardozo et al., 2001).

Calcium participates on the formation of plant cell wall (Malinovsky et al.,2014) and is a nutrient transported by the xylem from the roots. At the end of cell division and the beginning of cell growth, small amounts of calcium reach fruit tissues (Hahn et al., 2017). Calcium deficiency leads to the development of apical rot or black rot in fruits (Arruda Júnior et al., 2011; Hahn et al., 2017). Boron acts as a transducer in lightinitiated processes, sugar translocation, and cell wall formation (GonzálezFontes et al., 2008; Zhou et al., 2016) and is essential for the formation of the pollen tube and fertilization and development of fruits (Ganie et al., 2013).
Plant regulators are substances that can produce an effect similar to that of plant hormones (Albrecht et al., 2012; Palangana et al., 2012). In agriculture, plant regulators are used for a variety of purposes, including increasing plant development and yield, stimulating rooting of cuttings, promoting dormancy in fruits, stimulating sprouting, slowing or accelerating fruit ripening, and controlling plant development to facilitate cultural treatment and harvest 
(Fagan et al., 2016a). Therefore, plant regulators can promote, inhibit, or modify physiological processes in plants (Fagan et al., 2016a).

The cultivation of bell peppers is usually difficult, and fruit yield is not always satisfactory. This aspect becomes even more critical in the field cultivation of bell peppers, in which edaphoclimatic conditions during the crop cycle are not always adequate and may limit the productive potential. Therefore, the foliar application of plant regulators and mineral nutrients is a feasible strategy to obtain higher yields, higher quality of the final product, and commercial competitiveness (Palangana et al., 2012; Pérez-Jiménez et al., 2015).

Studies have demonstrated the positive effects of foliar sprays with calcium (Borges et al., 2005), boron (Mashayekhi et al., 2015), and plant growth regulators (Palangana et al., 2012; Pérez-Jiménez et al., 2015) on the vegetative and productive development of fruits and vegetables. Palangana et al. (2012) observed that leaf spraying with the plant growth regulator Stimulate at a dose of $150 \mathrm{~mL}$ p.c. $100 \mathrm{~L}^{-1}$ of spray volume increased the production of bell peppers. However, few studies to date evaluated the foliar application of boron and calcium in bell pepper production or the concomitant use of these nutrients with plant growth regulators.

Bell peppers are susceptible to calcium deficiency (Silva et al., 2017) and boron deficiency (Mello et al., 2002). The spraying of these nutrients, together with plant regulators, on leaves and flowers can increase the rate of gas exchange, promote plant development, and increase fruit yield.

The objective of this study was to evaluate the effect of isolated and combined foliar application of boron, calcium, and the plant regulator Stimulate on bell pepper production.

\section{MATERIAL AND METHODS}

This study was carried out at Universidade Estadual do CentroOeste (UNICENTRO) located in the municipality of Guarapuava

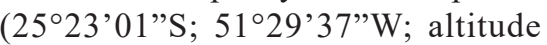

1100 m), Paraná, Brazil. The local climate is classified as $\mathrm{Cfb}$ (humid subtropical) by Köppen classification, with hot summers, high occurrence of frost in winters, $17^{\circ} \mathrm{C}$ annual mean temperature, and $1,946 \mathrm{~mm}$ annual average rainfall (Wrege et al., 2011). The local soil is classified as typical Dystroferric Bruno Latosol, clayey texture.

We used a completely randomized block design, three replicates, and nine plants on each plot. The treatments involved the isolated or combined foliar application of fertilizers Boron Super at a concentration of $0.01 \%$ boron by spray volume $\left(\mathrm{H}_{2} \mathrm{O}\right)$, calcium chloride $\left(\mathrm{CaCl}_{2}\right)$ at a concentration of $0.04 \%$ calcium by spray volume $\left(\mathrm{H}_{2} \mathrm{O}\right)$, and plant regulator Stimulate [a mixture of kinetin $(90 \mathrm{mg}$ $\left.\mathrm{L}^{-1}\right), 4$-(indol-3-yl)butyric acid (50 mg $\mathrm{L}^{-1}$ ), and gibberellic acid (as $\mathrm{GA}_{3}, 50 \mathrm{mg}$ $\left.\mathrm{L}^{-1}\right)$ ] at a concentration of $150 \mathrm{~mL}$ p.c. $100 \mathrm{~L}$ of spray volume $\left(\mathrm{H}_{2} \mathrm{O}\right)$.

Seedlings were obtained by planting the All Big cultivar (ISLA Sementes ${ }^{\circledR}$ ) in 200-cell expanded polystyrene trays containing a pine bark-based commercial biostabilized substrate. Seedlings with four to five leaves were transplanted in the field 49 days after sowing.

The soil was plowed to prepare the experimental area in the field, and a bed shaper was used for preparing beds, 1.0 $\mathrm{m}$ width. The soil was corrected with 1.79 tons of calcitic limestone (PRNT $100 \%)$ per hectare according to the results of soil analysis to reach a base saturation of $80 \%$. After liming, the soil was tilled, and beds covered with a $3 \mathrm{~cm}$ layer of organic compost + corn straw.

Seedlings were transplanted at $1.2 \times 0.4 \mathrm{~m}$ spacing and density of 2.08 plants $\mathrm{m}^{-2}$. Plants were staked vertically using bamboo stakes. Drip irrigation was performed according to the water requirement of the crop.

For the development and daily application of fertigation, the recommendations of Trani \& Carrijo (2011) were adopted according to the development stage of the crop in clayey soils, using the following nutrient combination 1) first phase (up to 15 days after transplanting), $0.23 \mathrm{~kg}$ of nitrogen $(\mathrm{N}), 0.30 \mathrm{~kg}$ of calcium $(\mathrm{Ca})$,
$0.51 \mathrm{~kg}$ of phosphorus (P), and $0.33 \mathrm{~kg}$ of potassium (K) per ha; 2 ) second phase (16 to 30 days after transplanting), 1.22 $\mathrm{kg}$ of N, $1.20 \mathrm{~kg}$ of Ca, $0.77 \mathrm{~kg}$ of P, and $1.60 \mathrm{~kg}$ of $\mathrm{K}$ per ha; 3 ) third phase (31 to 45 days after transplanting), $1.20 \mathrm{~kg}$ of $\mathrm{N}, 1.60 \mathrm{~kg}$ of Ca, $2.04 \mathrm{~kg}$ of $\mathrm{P}$, and $1.32 \mathrm{~kg}$ of K per ha; 4) fourth phase (46 to 60 days after transplanting), $1.43 \mathrm{~kg}$ of $\mathrm{N}, 0.90 \mathrm{~kg}$ of Ca, $0.92 \mathrm{~kg}$ of P, and $3.45 \mathrm{~kg}$ of $\mathrm{K}$ per ha; 5) fifth phase (61 days after transplanting to the end of the crop cycle), $2.32 \mathrm{~kg}$ of N, $1.30 \mathrm{~kg}$ of Ca, $0.27 \mathrm{~kg}$ of $\mathrm{P}$, and $2.16 \mathrm{~kg}$ of $\mathrm{K}$ per ha. We used the fertilizers calcium nitrate, potassium nitrate, and monopotassium phosphate (MPK).

During the crop cycle, only the branches and leaves below the first bifurcation were pruned. Weed control was performed manually. Phytosanitary control was performed preventively with sprays containing thiamethoxam (Actara), copper oxychloride + mancozeb (Cuprozeb), and difenoconazole (Score) according to manufacturers' recommendations for the crop.

Foliar applications were performed using a costal sprayer [with a constant pressure valve (Jacto), $2 \mathrm{kgf} \mathrm{\textrm {cm } ^ { - 2 }}$ pressure, and a cone-shaped nozzle X2 $(2 / 110)]$ at $1.05 \mathrm{~m} \mathrm{~s}^{-1}$ speed and $240 \mathrm{~L}$ ha $^{-1}$ volume. Plastic curtains were used to avoid contaminating adjacent plots.

Gas exchange was analyzed using a portable photosynthesis system (IRGA, Infrared Gas Analyzer, LiCor, LI6400XT) with $1000 \mu \mathrm{mol}$ photons $\mathrm{m}^{-2} \mathrm{~s}^{-1}, 400 \mu \mathrm{mol} \mathrm{mol}^{-1}$ of $\mathrm{CO}_{2}$, and $\Delta \mathrm{CO}_{2}+\Delta \mathrm{H}_{2} 0$ lower than $1 \%$, by measuring the photosynthetic yield or net assimilation $\left(A, \mu \mathrm{mol} \mathrm{CO} \mathrm{m}^{-2}\right.$ $\left.\mathrm{s}^{-1}\right)$, internal $\mathrm{CO}_{2}$ concentration $(\mathrm{Ci}$, $\left.\mu \mathrm{mol} \mathrm{mol}^{-1}\right)$, and transpiration rate $(E$, mmol $\left.\mathrm{H}_{2} \mathrm{O} \mathrm{m}^{-2} \mathrm{~s}^{-1}\right)$. The three central plants of each plot were evaluated in the third fully expanded leaf from the apex. Measurements were made from 10:00 a.m. to $12: 00$ p.m. during full blooming (January 20 to 22, 2014) and the beginning of fruiting (February 17 to 19,2014$)$. All plots were evaluated on three dates in each phase, and one block was evaluated per date in sunny conditions.

Fruits that changed color from green 
to bluish-green were harvested from five central plants in each plot on the following dates: February 17, February 27; March 10; and April 1, 2014. Fruits with a length $>60 \mathrm{~mm}$ and diameter $>40 \mathrm{~mm}$ were considered marketable and, those $<60 \mathrm{~mm}$ in length and $<40$ $\mathrm{mm}$ diameter were classified as nonmarketable, including those with severe defects, including wilting, deterioration, malformation, disease, or mechanical or pest insect damage, according to Araújo et al. (2009).

The agronomic characteristics we evaluated were number of marketable and non-marketable fruits (fruits $\mathrm{m}^{-2}$ ), production of marketable and nonmarketable fruits $\left(\mathrm{g} \mathrm{m}^{-2}\right)$, average mass of commercial fruits $\left(\mathrm{g}\right.$ fruit $\left.^{1}\right)$, volume of commercial fruits $(\mathrm{mL})$ (determined individually in fruits classified by commercial standards based on the displacement of water contained in a 2-L beaker), and fruit firmness (N) [in fruits classified by commercial standards using a digital penetrometer (Instrutherm DD-200) with a 8-mm tip] by compressing two areas in the central region of whole fruits [results expressed in Newton $(\mathrm{N})$ ].

The obtained data were tested for normality of residuals, homogeneity of residual variances, and block additivity. After that, analysis of variance was conducted using the $\mathrm{F}$ test. When significant, the effect of isolated and combined foliar sprays with boron, calcium, and Stimulate was compared with that of the control treatment using the Dunnett test and the statistical software ASSISTAT version 7.7 at 5\% significance level (Silva \& Azevedo, 2016). The contrasts of interest for agronomic characteristics (isolated and combined foliar application of boron, calcium, and Stimulate) between the groups were estimated using the Scheffé test and the SISVAR software version 5.6 (Ferreira, 2008).

\section{RESULTS AND DISCUSSION}

All treatments with isolated and combined application of boron, calcium, and Stimulate increased fruit yield compared with the control treatment,

Table 1. Number and productivity of marketable (M) and non-marketable (NM) fruits and average mass of marketable fruits (AMC) in bell pepper plants, sprayed isolated and combined with boron, calcium and commercial plant regulator Stimulate. Guarapuava, UNICENTRO, $2013 / 2014$.

\begin{tabular}{|c|c|c|c|c|c|}
\hline \multirow{2}{*}{ Treatments } & \multicolumn{2}{|c|}{ Fruits $\mathbf{m}^{-2}$} & \multicolumn{2}{|c|}{ Production $\left(\mathrm{g} \mathrm{m}^{-2}\right)$} & \multirow{2}{*}{ AMC (g fruit $^{-1}$} \\
\hline & $\mathbf{M}^{1}$ & $\mathbf{N M}^{2}$ & $\mathbf{M}$ & NM & \\
\hline Boron & $25.2 *$ & 6.9 & $1095.5^{*}$ & 101.5 & 130.7 \\
\hline Calcium & 19.8 & 4.6 & 942.5 & $72.8 *$ & 152.3 \\
\hline Stimulate & 24.5 & $8.1^{*}$ & 941.5 & 124.6 & 115.9 \\
\hline Boron + calcium & $29.1 *$ & $8.3^{*}$ & $1201.4 *$ & 108.2 & 123.7 \\
\hline Boron + Stimulate & $27.2 *$ & $11.0^{*}$ & $1003.1 *$ & 142.1 & $110.4^{*}$ \\
\hline Cálcio + Stimulate & 22.9 & $8.1^{*}$ & $1001.9 *$ & 146.1 & 131.7 \\
\hline Boron + calcium + Stimulate & $26.2 *$ & $10.0^{*}$ & $1039.7 *$ & 120.2 & 119.5 \\
\hline Control & 20.6 & 4.6 & 932.5 & 98.5 & 136.0 \\
\hline $\mathrm{CV}(\%)$ & 7.4 & 14.7 & 5.04 & 16.1 & 6.93 \\
\hline \multicolumn{6}{|l|}{ Estimating the contrasts of interest } \\
\hline Boron isolated vs. calcium isolated & $5.4^{+}$ & $2.3^{+}$ & $153.0^{+}$ & $28.7^{+}$ & $-21.6^{+}$ \\
\hline Boron isolated vs. Stimulate isolated & 0.6 & -1.2 & $154.0^{+}$ & $-23.1^{+}$ & 14.8 \\
\hline Calcium isolated vs. Stimulate isolated & $-4.8^{+}$ & $-3.5^{+}$ & 1.0 & $-51.8^{+}$ & $36.4^{+}$ \\
\hline Boron isolated vs. boron + calcium & -4.0 & -1.5 & $-105.9^{+}$ & -6.7 & 7.0 \\
\hline Boron isolated vs. boron + Stimulate & -2.1 & $-4.2^{+}$ & $92.4^{+}$ & $-40.6^{+}$ & $20.3^{+}$ \\
\hline Boron isolated vs. calcium + Stimulate & 2.3 & -1.2 & $93.6^{+}$ & $-44.6^{+}$ & -1.0 \\
\hline Boron isolated vs. boron + calcium + Stimulate & -1.0 & -3.1 & 55.8 & -18.7 & 11.2 \\
\hline Calcium isolated vs. boron + calcium & $-9.4^{+}$ & $-3.7^{+}$ & $-258.9^{+}$ & $-35.4^{+}$ & $28.6^{+}$ \\
\hline Calcium isolated vs. boron + Stimulate & $-7.5^{+}$ & $-6.4^{+}$ & -60.6 & $-69.3^{+}$ & $41.9^{+}$ \\
\hline Calcium isolated vs. calcium + Stimulate & -3.1 & $-3.5^{+}$ & -59.4 & $-73.3^{+}$ & $20.6^{+}$ \\
\hline Calcium isolated vs. boron + calcium + Stimulate & $-6.4^{+}$ & $-5.4^{+}$ & $-97.2^{+}$ & $-47.4^{+}$ & $32.8^{+}$ \\
\hline Stimulate isolated vs. boron + calcium & $-4.6^{+}$ & -0.2 & $-259.9^{+}$ & 16.4 & -7.8 \\
\hline Stimulate isolated vs. boron + Stimulate & -2.7 & -2.9 & -61.6 & -17.5 & 5.5 \\
\hline Stimulate isolated vs. calcium + Stimulate & 1.7 & 0.0 & -60.4 & $-21.5^{+}$ & -15.8 \\
\hline Stimulate isolated vs. boron + calcium + Stimulate & -1.7 & -1.9 & $-98.2^{+}$ & 4.4 & -3.6 \\
\hline
\end{tabular}

*Different from control by Dunnett's level $(\mathrm{P}<0.05)$; ${ }^{+}$significant contrast by Scheffé test, $1 \%$ probability. 
except for calcium and Stimulate alone (Table 1). Furthermore, boron alone, boron + calcium, boron + Stimulate, and boron + calcium + Stimulate increased the number of marketable fruits compared with the control (Table $1)$.

The analysis of the contrasts of interest indicated that boron either alone or in combination produced a higher number of commercial fruits than calcium alone. Boron alone produced a higher fruit yield than calcium and Stimulate in isolation; boron + calcium was better than boron, calcium, and Stimulate alone; and boron + calcium + Stimulate was better than calcium and

Stimulate alone (Table 1). These results suggest that foliar sprays containing boron were more effective in fixing fruits than the other treatments.

The positive effect of boron on fruit yield may be due to improvements in the physiological processes of plants. Boron is involved in the synthesis, lignification, and composition of the cell wall, sugar transport, and respiration (Fagan et al., 2016b). Moreover, these authors have shown that boron is essential for reproductive growth and development, nitrogen fixation, and cell membrane structuring.

Treatments with isolated and combined foliar sprays were not

Table 2. Volume and firmness of marketable fruits in bell pepper plants with spraying isolated and combined of boron, calcium and commercial plant regulator Stimulate. Guarapuava, UNICENTRO, 2013/2014.

\begin{tabular}{|c|c|c|}
\hline Treatments & $\begin{array}{c}\text { Volume } \\
\left(\text { mL fruit }^{-1}\right)\end{array}$ & $\begin{array}{l}\text { Firmness } \\
(\mathbf{N})\end{array}$ \\
\hline Boron & 282.2 & 33.4 \\
\hline Calcium & 309.9 & $41.1 *$ \\
\hline Stimulate & $247.7 *$ & 30.9 \\
\hline Boron + calcium & 269.0 & 33.9 \\
\hline Boron + Stimulate & $226.7 *$ & 29.2 \\
\hline Cálcio + Stimulate & 281.4 & 31.8 \\
\hline Boron + calcium + Stimulate & $224.1 *$ & 28.1 \\
\hline Control & 292.9 & 33.9 \\
\hline $\mathrm{CV}(\%)$ & 6.4 & 12.62 \\
\hline \multicolumn{3}{|l|}{ Estimating the contrasts of interest } \\
\hline Boron isolated vs. calcium isolated & -27.7 & $-7.7^{+}$ \\
\hline Boron isolated vs. Stimulate isolated & $34.5^{+}$ & 2.5 \\
\hline Calcium isolated vs. Stimulate isolated & $62.2^{+}$ & $10.2^{+}$ \\
\hline Boron isolated vs. boron + calcium & 13.2 & -0.5 \\
\hline Boron isolated vs. boron + Stimulate & $55.5^{+}$ & 4.2 \\
\hline Boron isolated vs. calcium + Stimulate & 0.8 & 1.6 \\
\hline Boron isolated vs. boron + calcium + Stimulate & $58.1^{+}$ & 5.3 \\
\hline Calcium isolated vs. boron + calcium & $40.9^{+}$ & $7.2^{+}$ \\
\hline Calcium isolated vs. boron + Stimulate & $83.2^{+}$ & $11.9^{+}$ \\
\hline Calcium isolated vs. calcium + Stimulate & 28.5 & $9.3^{+}$ \\
\hline Calcium isolated vs. boron + calcium + Stimulate & 85.8 & $13.0^{+}$ \\
\hline Stimulate isolated vs. boron + calcium & -21.3 & -3.0 \\
\hline Stimulate isolated vs. boron + Stimulate & 21.0 & 1.7 \\
\hline Stimulate isolated vs. calcium + Stimulate & $-33.7^{+}$ & -0.9 \\
\hline $\begin{array}{l}\text { Stimulate isolated vs. boron }+ \text { calcium }+ \\
\text { Stimulate }\end{array}$ & 23.6 & 2.8 \\
\hline
\end{tabular}

*Different from control by Dunnett's level $(\mathrm{P}<0.05)$; ${ }^{+}$significant contrast by Scheffé test, $1 \%$ probability. significantly different from the controls for average mass of commercial fruits, except for boron + Stimulate, which decreased fruit mass (Table 1). This treatment, together with Stimulate alone and boron + calcium + Stimulate, reduced the volume of marketable fruits relative to the control (Table 2).

Calcium alone did not change the characteristics of commercial fruits when compared to the control but decreased the yield of non-commercial fruits relative to the control. The analysis of the contrasts of interest revealed that calcium produced a higher average mass of marketable fruits when compared to boron and Stimulate alone or in combination (Table 1).

A possible explanation for the absence of the effect of calcium on the production of commercial fruits (number and yield of fruits) was that, during the crop cycle, the plants received fertigation containing calcium nitrate. However, calcium spraying decreased the yield of non-commercial fruits (Table 1) and increased fruit firmness (Table 2) compared to the control treatment. With respect to the latter characteristic, calcium in isolation differed from boron and Stimulate either alone or in combination (Table 2).

The greater firmness of fruits from plants treated with calcium compared to the control treatment can be attributed to the structural function of calcium in forming the cell wall of fruits. The binding of calcium to fruit pectins inhibits the solubilization of polyuronides and provides a more rigid structure to the middle lamella (greater firmness) (Glenn et al., 1988). Senescence of tissues is affected to some extent by the degradation of pectic polymers in the cell wall, and fruits with high calcium levels show increased firmness and consequently longer shelflife (Pereira et al., 2002). The increase in fruit firmness by calcium was also observed in other fruit species, including blueberry (Ochmian, 2012), apple (Rose \& Drake, 2008), kiwi (Koutinas et al., 2010), and cherry (Brown et al., 1996).

The spraying of Stimulate increased the number, yield, and average mass of commercial fruits relative to the control only when this product was 
Table 3. Photosynthetic yield $(A)$, internal $\mathrm{CO}_{2}$ concentration $(C i)$, and transpiration rate $(E)$ in bell pepper plants with spraying isolated and combined of boron, calcium and commercial plant regulator Stimulate. Guarapuava, UNICENTRO, 2013/2014.

\begin{tabular}{|c|c|c|c|c|c|c|}
\hline \multirow{2}{*}{ Treatments } & \multicolumn{2}{|c|}{$A\left(\mu \mathrm{mol} \mathrm{CO}_{2} \mathrm{~m}^{-2} \mathrm{~s}^{-1}\right)$} & \multicolumn{2}{|c|}{$\mathrm{Ci}\left(\mu \mathrm{mol} \mathrm{mol}{ }^{-1}\right)$} & \multicolumn{2}{|c|}{$E\left(\mathrm{mmol} \mathrm{H}_{2} \mathrm{O} \mathbf{m}^{-2} \mathbf{s}^{-1}\right)$} \\
\hline & $\mathrm{Fl}^{1}$ & $\mathbf{F s}^{2}$ & Fl & Fs & FI & Fs \\
\hline Boron & $22.3^{*}$ & $21.9^{*}$ & $117.6^{*}$ & $112.6^{*}$ & $8.0^{*}$ & $7.1^{*}$ \\
\hline Calcium & 20.4 & 19.8 & $156.7^{*}$ & 167.1 & 6.3 & 5.0 \\
\hline Stimulate & 20.2 & 20.2 & 160.2 & 162.6 & 6.9 & $6.9^{*}$ \\
\hline Boron + calcium & $22.2 *$ & $21.9^{*}$ & $121.6^{*}$ & $107.5^{*}$ & $7.9^{*}$ & 5.8 \\
\hline Boron + Stimulate & 19.9 & 19.9 & 163.5 & 171.1 & 6.1 & 5.7 \\
\hline Cálcio + Stimulate & 20.1 & 19.6 & 193.6 & 165.4 & 6.6 & 5.5 \\
\hline Boron + calcium + Stimulate & 20.9 & 20.3 & 165.2 & 165.3 & 6.9 & 5.6 \\
\hline Control & 17.75 & 19.4 & 197.9 & 166.4 & 5.9 & 5.8 \\
\hline CV (\%) & 6.6 & 6.7 & 10.6 & 11.4 & 9.8 & 12.0 \\
\hline
\end{tabular}

*Different from control by Dunnett's level $(\mathrm{P}<0.05) ;{ }^{1}$ full flowering $(\mathrm{Fl}) ;{ }^{2}$ fruiting start (Fs).

combined with boron and/or calcium (Table 1), suggesting that Stimulate did not improve the main characteristics in field-cultivated bell peppers. In addition, the positive effects of Stimulate + boron were primarily due to the improvements caused by boron.

Increased fruit yields using Stimulate is reported in the literature for bell peppers (Palangana et al., 2012), cabbage (Zeist et al., 2017b), and soybean (Albrecht et al., 2012). However, in the present study, Stimulate improved only the volume of marketable fruits relative to the control. Plant regulators do not always increase fruit yield, as reported by Ataíde et al. (2006) using sprays containing Stimulate and $\mathrm{GA}_{3}$ in passion fruit.

Boron alone and boron + calcium significantly improved gas exchange relative to the control both in full bloom and at the beginning of fruiting (Table 3). In this respect, Thurzó et al. (2010) observed that boron increased the levels of photosynthetic pigments in Prunus avium, and Liu et al. (2015) found that calcium increased the photosynthetic activity of tomato plants under low temperatures at night.

Boron alone and boron + calcium increased the photosynthetic yield and transpiration rate when compared to the control but resulted in the lowest intracellular $\mathrm{CO}_{2}$ concentrations (Table $3)$. The photosynthetic yield is usually dependent on the transpiration rate (Ferraz et al., 2012), and these parameters tend to be inversely correlated with the internal $\mathrm{CO}_{2}$ concentration (Zeist et al., $2017 \mathrm{a}, \mathrm{b})$. The explanation for this result is that, the higher the net assimilation of $\mathrm{CO}_{2}$ and water absorption and diffusion, the higher is the use of intracellular $\mathrm{CO}_{2}$ by Rubisco in the Calvin cycle. Dalastra et al. (2014) evaluated gas exchange in Sancho melon, 56 days after transplanting, and observed that the photosynthetic yield was increased as the intracellular $\mathrm{CO}_{2}$ concentration was decreased.

The treatments that improved the agronomic characteristics and photosynthetic yield of bell peppers compared to the control contained boron. Evidence of the increased fruit yield by boron has also been reported for other agricultural crops using boron (Al-Amery et al., 2011) and boron + zinc (Wasaya et al., 2017).

Mello et al. (2002) emphasize the importance of boron in the development and yield of bell peppers. These authors observed that boron deficiency might decrease root volume, foliar area, photosynthetic yield, and production of branches and flowers. Moreover, boron deficiency leads to the deficiency of other essential nutrients by affecting their rate of absorption and use.

The results indicate that the biweekly application of boron $(0.01 \%)$ on the leaves from the beginning of flowering increases the photosynthetic yield and yield of marketable bell peppers cultivated in the field. There were no beneficial effects of the foliar application of calcium and Stimulate on gas exchange and fruit yield. The most common effects of boron were an increase in the number of marketable fruits. Biweekly foliar sprays with calcium $(0.01 \%)$ from the beginning of flowering increased the firmness of commercial bell peppers.

\section{REFERENCES}

AL-AMERY, MM; HAMZA, JH; FULLER, MP. 2011. Effect of boron foliar application on reproductive growth of sunflower (Helianthus annuus L.). International Journal of Agronomy 2011: 1-6.

ALBRECHT, LP; BRACCINI, A; SCAPIM, CA; ÁVILA, MR; ALBRECHT, AJP. 2012. Biorregulador na composição química e na produtividade de grãos de soja. Ciência Agronômica 43: 774-782.

ARAÚJO, JS; ANDRADE, AP; RAMALHO, CI; AZEVEDO, CAV. 2009. Características e frutos de pimentão cultivado em ambiente protegido sob doses de nitrogênio via fertirrigação. Engenharia Agrícola e Ambiental 13: 152-157.

ARRUDA JUNIOR, SJ; BEZERRA NETO, E; BARRETO, LP; RESENDE, LV. 2011. Podridão apical e produtividade do tomateiro em função dos teores de cálcio e amônio. Caatinga 24: 20-26.

ATAÍDE, EM; RUGGIERO, C; OLIVEIRA, JC; RODRIGUES, JD; BARBOSA, JC. 2006. Efeito de giberelina $\left(\mathrm{GA}_{3}\right)$ e do bioestimulante 'Stimulate' na indução floral e produtividade do maracujazeiro-amarelo em condições de safra normal. Revista Brasileira de Fruticultura 28: 343-346.

BROWN, GS; KITCHENER, AE; GLASSON, WB; BARNES, S. 1996. The effects of copper and calcium foliar sprays on cherry and apple fruit quality. Scientia Horticulturae 67: 219-227.

CARDOZO, VP; PIZETTA, NV; TEIXEIRA, NT. 2001. Adubação foliar com cálcio e boro na 
cultura do tomate (Lycopersicum esculentum Mill) Cv. Débora max. Ecossistema 26: 39-39.

DALASTRA, GM; ECHER, MM; GUIMARÃES, VF; HACHMANN, TL; INAGAKI, AM. 2014. Trocas gasosas e produtividade de três cultivares de meloeiro conduzidas com um e dois frutos por planta. Bragantia 73: 365-371.

FAGAN, EB; ONO, EO; RODRIGUES, JD; CHALFUN JÚNIOR, A; DOURADO NETO, D. 2016a. Fisiologia vegetal: reguladores vegetais. Piracicaba: Andrei. 300p.

FAGAN, EB; ONO, EO; RODRIGUES, JD; SOARES, LH; DOURADO NETO, D. 2016 b. Fisiologia vegetal: metabolismo e nutrição mineral. Piracicaba: Andrei. 305p.

FERRAZ, RLS; MELO, AS; SUASSUNA, JF; RITO, MEB; FERNANDES, PD; NUNES JUNIOR, ES. 2012. Trocas gasosas e eficiência fotossintética em ecotipos de feijoeiro cultivados no semiárido. Pesquisa Agropecuária Tropical 42: 181-188.

FERREIRA, DF. 2008. SISVAR: um programa para análises e ensino de estatística. Symposium 6: 36-41.

GANIE, MA; AKHTER, F; BHAT, MA; MALIK, AR; JUNAID, JM; SHAH, MA; BHAT, AH; BHAT, TA. 2013. Boron - a critical nutrient element for plant growth and productivity with reference to temperate fruits. Current Science 104: 76-85.

GLENN, GM; REDDY, ASN; POOVAIAH, BW. 1988. Effect of calcium on cell wall structure, protein phosphorylation and protein profile in senescence apples. Plant Cell Physiology 29: 565-573.

GONZÁLEZ-FONTES, A; REXACH, J; NAVARRO-GOCHICOA, MT; HERRERA-RODRÍGUEZ, MB; BEATO, VM; MALDONADO, JM; CAMACHOCRISTÓBAL, JJ. 2008. Is boron involved solely in structural roles in vascular plants? Plant Signaling \& Behavior 3: 24-26.

HAHN,L; SUZUKI, A; FELTRIM,AL; WAMSER, AF; MUELLER, S; VALMORBIDA, J. 2017. Aplicação de formulações de cálcio e boro na cultura do tomateiro tutorado. Agropecuária Catarinense 30: 61-66.

KAZEMI, M. 2014. Effect of foliar application of humic acid and calcium chloride on tomato growth. Bulletin of Environment, Pharmacology and Life Sciences 3: 41-46.

KOUTINAS, N; SOTIROPOULOS, T; PETRIDIS, A; ALMALIOTIS, D; DELIGEORGIS, E;
THERIOS, I; VOULGARAKIS, N. 2010. Effects of preharvest calcium foliar sprays on several fruit quality attributes and nutritional status of the kiwifruit cultivar Tsechelidis. HortScience 45: 984-987.

LIU, YU; ZHANG, G; QI, M; LI, T. 2015. Effects of calcium on photosynthesis, antioxidant system, and chloroplast ultrastructure in tomato leaves under low night temperature stress. Journal of Plant Growth Regulation 34: 263-273.

MALINOVSKY, FG; FANGEL, JU; WILLATS, WGT. 2014. The role of the cell wall in plant immunity. Frontiers in Plant Science 5: 1-12.

MASHAYEKHI, K; DEHKORDI, AG; KAMKAR, B; AZBARMI, R. 2015. Foliar spray of sucrose and boron on some characters of leaf and fruit of tomato Var. super A. International Journal of Analytical, Pharmaceutical and Biomedical Sciences 4: 51-61.

MELLO, SC; DECHEN, AR; MINAMI, K. 2002. Influência do boro no desenvolvimento e na composição mineral do pimentão. Horticultura Brasileira 20: 99-102.

OCHMIAN, I. 2012. The impact of foliar application of calcium fertilizers on the quality of highbush blueberry fruits belonging to the 'Duke' cultivar. Notulae Botanicae Horti Agrobotanici 40: 163-169.

PALANGANA, FC; SILVA, ES; GOTO, R; ONO, EO. 2012. Ação conjunta de citocinina, giberelina e auxina em pimentão enxertado e não enxertado sob cultivo protegido. Horticultura Brasileira 30: 751-755.

PEREIRA, AJ; BLANK, AF; ALVARENGA, MAR; SOUZA, RJ. 2002. Aplicação de fontes e doses de cálcio na produção e qualidade de frutos de melão. Horticultura Brasileira 20: 428-431.

PÉREZ-JIMÉNEZA, M; PAZOS-NAVARROB, M; LÓPEZ-MARÍNA, J; GÁLVEZA, A; VARÓC, P; AMORA, FM. 2015. Foliar application of plant growth regulators changes the nutrient composition of sweet pepper (Capsicum annuum L.). Scientia Horticulturae 194: 188-193.

RAESE, JT; DRAKE, SR. 2008. Effect of calcium spray materials, rate, time of spray application, and rootstocks on fruit quality of 'Red' and 'Golden delicious' apples. Journal of Plant Nutrition 23: 1435-1447.

SILVA, AZ; WAMSER, AF; NOWAKI, RH;
CECÍLIO FILHO, AB; MENDOZACORTEZ, JW. 2017. Síntomas de deficiencia de macronutrientes en pimiento (Capsicum annuит L.). Agrociencia Uruguay 21: 31-43.

SILVA, FAS; AZEVEDO, CAV. 2016. The assistat software version 7.7 and its use in the analysis of experimental data. African Journal of Agricultural Research 11: 3733-3740.

SILVA, MW; JADOSKI, CJ; ONO, EO; GOTO, R. 2009. Cálcio, boro e reguladores vegetais na fixação de frutos em tomateiro. Pesquisa Aplicada \& Agrotecnologia 2: 103-106.

THURZÓ, S; SZABÓ, Z; NYÉKI, J; NAGY, PT; SILVA, AP; GONÇALVES, B. 2010. Effect of boron and calcium sprays on photosynthetic pigments, total phenols and flavonoid content of sweet cherry (Prunus avium L.). Acta Horticulturae 868: 457-461.

TRANI, PE; TIVELLI, SW; CARRIJO, OA. 2011. Fertirrigação em hortaliças. 2. ${ }^{a}$ ed. Campinas: Instituto Agronômico, Série Tecnologia APTA, Boletim Técnico IAC, 196. 51p.

WASAYA, L; SHABIR, MS; HUSSAIN, M; ANSAR, M; AZIZ, A; HASSAN, W; AHMAD, I. 2017. Foliar application of zinc and boron improved the productivity and net returns of maize grown under rainfed conditions of Pothwar plateau. Journal of Soil Science and Plant Nutrition 17: 33-45.

WREGE, MS; STEINMETZ, S; REISSER JUNIOR, C; ALMEIDA, IR. 2011. Atlas climático da Região Sul do Brasil: Estados do Paraná, Santa Catarina e Rio Grande do Sul. 1. Pelotas: Embrapa Clima Temperado, Colombo: Embrapa Florestas. 336p.

ZEIST, AR; RESENDE, JTV; SILVA, IFL; OLIVEIRA, JRF; FARIA, CMDR; GIACOBBO, CL. 2017a. Agronomic characteristics of tomato plant cultivar Santa Cruz Kada grafted on species of the genus Solanum. Horticultura Brasileira 35: 419-424.

ZEIST, AR; PIVA, R; RESENDE, JTV; SILVA, IFL; ATHANAZIO, JC; RODRIGUES, JD. 2017b. Physiological and agronomic traits of cabbage plants hybrid Fuyutoyo ${ }^{\circledR}$ sprayed with plant growth regulators. Horticultura Brasileira 35: 2010-2015.

ZHOU, T; HUA, Y; HUANG, Y; DING, G, SHI, L; XU, F. 2016. Physiological and transcriptional analyses reveal differential phytohormone responses to boron deficiency in Brassica napus genotypes. Frontiers in Plant Science 7: 1-16. 